[Agr. Biol. Chem., Vol. 33, No. 2, p. 225 229, 1969]

\title{
Syntheses of Unsaturated Lactones
}

\section{Part II. Flavorous Nature of Some 4- and 5-Substituted- 5-Hydroxy-2-Enoic Acid Lactones}

\author{
By Akio Nobuhara \\ Central Research Institute of Kikkoman Shoyu Co., Ltd., \\ Noda-shi, Chiba-ken, Japan \\ Received July 12, 1968
}

\begin{abstract}
Homologous 4- and 5-substituted 5-hydroxy-2-enoic acid lactones were prepared, :and the nature of their flavors as a butter cake flavor was investigated. Among those, unsaturated lactones having the best flavorous nature have the following structural properties. The length of a substituted residue at the $\gamma$-position of the lactone ring should be as short as possible. The lactones have a $n$-amyl residue at the $\delta$-position, and the total carbon number of a compound is ten. Namely, a compound is so better as to have a structure similar to that of 5-hydroxy-2-decenoic acid lactone.
\end{abstract}

A previous paper ${ }^{11}$ in this series reported the syntheses and flavorous nature of some lactones of 5-substituted-5-hydroxy-2-enoic acid (type I). This paper describes syntheses of seven lactones of 4- and 5-substituted-5-hydroxy-2enoic acid (type II) and the intermediates. Sensory evaluation of these compounds is also reported.

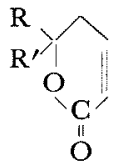

(I)

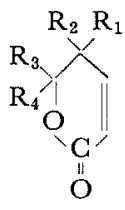

(II)
FIG. 1.

The synthetic scheme is shown in Fig. 2. The corresponding carbonyl compound was reacted with sodium acetylide in a liquid ammonia solution to give 1-yne-3-ol (III) as a colorless liquid. Bromination of the alcohol with phosphorus tribromide in the presence of

1) A. Nobuhara, Agr. Biol. Chem., 32, 1016 (1968). pyridine gave 3-bromo-1-yne (IV). The bromide was reacted with the corresponding carbonyl compound by the Reformatsky reaction to give 1-yne-4-ol (V). Thereafter, the method was virtually the same as that described in the previous paper. Carboxylation of the alcohol gave 5-hydroxy-2-ynoic acid (VI), and then, partial hydrogenation of the acid gave the lactone of 5-hydroxy-2-enoic acid (II) as a colorless liquid. The prepared homologous compounds are summarized in Fig. 3.

Since it has been reported in the previous paper that the unsaturated lactones having ten carbon number were presumed to have the strongest butter or butter cake flavor, some analogs of 2-ene- $\delta$-lactone which have ten carbon number were prepared and sensory evaluation was conducted by the experienced panel members of our laboratory. The flavorous nature as a butter cake of 5-hydroxy-2decenoic acid lactone was better than that of 5-hydroxy-4-methyl-2-nonenoic acid lactone (VII), and the latter flavor was better than that of 4-ethyl-5-hydroxy-2-octenoic acid lactone (VIII). The flavor of 5-hydroxy-4- 

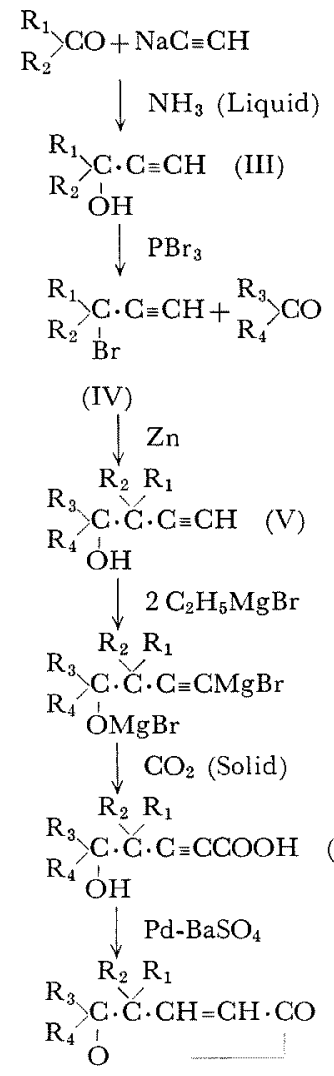

FIG. 2.<smiles>CCCCCCC</smiles>

(VII)<smiles>CCCCCC(C)C</smiles>

(XI)<smiles>CCCCCC(CC)C(C)CC</smiles>

(VIII)<smiles>CCCCC(CC)C(CC)OC(=O)CC</smiles>

(XII)

pentyl-2-pentenoic acid lactone (IX) was the worst of them. The flavor of 4,4-dimethyl5-hydroxy-2-octenoic acid lactone (X) was similar to that of menthol.

From the above mentioned result compounds having a $n$-amyl residue of the $\delta$-position in the lactone ring were expected to have a strong butter or butter cake flavor. Some analogs of 2-ene- $\delta$-lactones which satisfy this condition were prepared. The flavorous nature of 5hydroxy-2-decenoic acid lactone was better than that of 5-hydroxy-4-methyl-2-decenoic acid lactone (XI), the latter flavor was better than that of 4-ethyl-5-hydroxy-2-decenoic acid lactone (XII). The flavorous nature of 5hydroxy-5-methyl-2-decenoic acid lactone (XIII) was identical with that of 5-hydroxy-5methyl-2-nonenoic acid lactone which was reported in the previous paper, but the intensity of the former flavor was a little lower than that of the latter. The flavor intensity of 5-hydroxy-4-methyl-2-nonenoic acid lactone (VII) was a little stronger than that of 5hydroxy-4-methyl-2-decenoic acid lactone (XI).

In conclusion, unsaturated lactone having the best flavorous nature have the following structural properties. The length of a substituted residue at the $\gamma$-position of the lactone ring should be as short as possible. The lac-

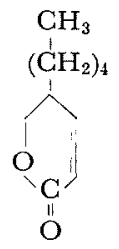

(IX)<smiles>CCC1(CC)OC(C)O1</smiles>

(XIII)<smiles>CCCCCCC</smiles>

(X)

FIG. 3. 
tones have a $n$-amyl residue at the $\delta$-position, and the total carbon number of a compound is ten. Namely, a compound is so better as to have a structure similar to that of 5-hydroxy2-decenoic acid lactone.

During the period of the experiments, Hashizume et al., ${ }^{2)}$ reported that 5-hydroxy-2decenoic acid lactone was isolated from cane molasses and that it showed a sugary flavor.

\section{EXPERIMENTAL}

\section{General methods}

A) 1-Yne-3-ol (III). The method used here was virtually identical with that of Jones et al.31 One mole of sodium acetylide was prepared by adding $23 \mathrm{~g}$ ( 1.0 gram atom) of sodium to about $500 \mathrm{ml}$ of liquid ammonia in the presence of a trace amount of hydrated ferric nitrate, while a rapid stream of dry acetylene was passing through the solvent. One mole of the corresponding aldehyde or ketone in about twice its volume of dry ether was added dropwise, with stirring, over a period of $1 \mathrm{hr}$. Stirring was continued for about $13 \mathrm{hr}$ more. The reaction was stopped by the gradual addition of $54 \mathrm{~g}$ ( 1 mole) of ammonium chloride. After the evaporation of ammonia, sufficient water was added to dissolve the inorganic salts, and the mixture was steam distilled. The product was salted out of the distillate with potassium carbonate and dried. Distillation gave 1-yne-3-ol (III) as a colorless liquid.

B) 3-Bromo-1-yne (IV). One mole of 1-yne-3-ol and $10 \mathrm{ml}$ of dry pyridine were treated with $95 \mathrm{~g}$ $(0.35$ mole $)$ of phosphorus tribromide in $100 \mathrm{ml}$ of dry ether at a temperature not exceeding $-10^{\circ} \mathrm{C}$. The reaction mixture was left to attain room temperature and then stirred for $3 \mathrm{hr}$. The product was poured into ice-water and extracted with ether. The ether solution was washed with a saturated solution of sodium bicarbonate and dried with anhydrous sodium sulfate. After removing the solvent and distilling in

2) T. Hashizume, N. Kikuchi, Y. Sasaki and I. Sakata, Abstracts of Papers, Annual Meeting of the Agricultural Chemical Society of Japan, Nagoya, April, 1968, p. 311 .

3) K. Bowden, I. M. Heilbron, E. R. H. Jones and B.C.L. Weedon, J. Chem. Soc., 1946, 39; I.M. Heilbron, E. R. H. Jones and B. C. L. Weedon, ibid., 1945, 81 . vacuo, 3-bromo-1-yne (IV) was obtained as a colorless liquid.

C) 1-Yne-4-ol $(V)$. To a boiling mixture of $65.4 \mathrm{~g}$ ( $1 \mathrm{gram}$ atom) of active zinc powder and $130 \mathrm{ml}$ of dry benzene were added with stirring a solution of 1.0 mole of the corresponding aldehyde or ketone, 1.0 mole of 3-bromo-1-yne (IV) and $250 \mathrm{ml}$ of dry ether. Addition of too much of the mixture at a time was avoided until reaction started. After the whole mixture was added, the content of the flask was refluxed for further $1.5 \mathrm{hr}$. The reaction mass was cooled and decomposed with $750 \mathrm{ml}$ of $10 \%$ acetic acid. The separated organic solvent was washed with a saturated solution of sodium bicarbonate and dried with anhydrous sodium sulfate. After removing the solvent and distilling in vacuo, 1-yne-4-ol (V) was obtained as a colorless liquid. The subsequent method was virtually identical with the general method described in the previous paper of this series.

Lactone of 5-hydroxy-4-methyl-2-nonenoic acid (VII)

A) I-Butyne-3-ol. (III, $\mathrm{R}_{1}=\mathrm{CH}_{3}, \mathrm{R}_{2}=\mathrm{H}$ ). This was prepared from $44.2 \mathrm{~g}$ ( 1 mole) of acetaldehyde by the general method. Yield $36.4 \mathrm{~g}(50 \%)$ ). Bp $105 \sim 110^{\circ} \mathrm{C}$.

B) 3-Bromo-1-butyne. (IV, $\mathrm{R}_{1}=\mathrm{CH}_{3}, \mathrm{R}_{2}=\mathrm{H}$ ). From $35 \mathrm{~g}(0.5 \mathrm{~mole})$ of 1 -butyne-3-ol, $34.5 \mathrm{~g}(52 \%)$ of 3 bromo-l-butyne was obtained. Bp $90 \sim 96^{\circ} \mathrm{C}$.

C) 3-Methyl-1-octyne-4-ol. (V, $\mathrm{R}_{1}=\mathrm{CH}_{3}, \mathrm{R}_{2}, \mathrm{R}_{4}=\mathrm{H}$, $\mathrm{R}_{3}=\mathrm{CH}_{3}\left(\mathrm{CH}_{2}\right)_{3}-$, $)$. The Reformatsky reaction of $17.2 \mathrm{~g}$ ( 0.2 mole) of valeraldehyde and $26.6 \mathrm{~g}$ (0.2 mole) of 3-bromo-I-butyne by the general method, gave $15.2 \mathrm{~g}$ (54.3\%) of the alcohol. Bp $109 \sim 115^{\circ} \mathrm{C} / 46 \mathrm{~mm}$. $n_{\mathrm{D}}^{21}$ 1.4451. Anal. Found: C, 76.46; H, 11.84. Calcd. for $\mathrm{C}_{9} \mathrm{H}_{16} \mathrm{O}: \mathrm{C}, 77.09 ; \mathrm{H}, 11.50 \%$.

D) 5-Hydroxy-4-methyl-2-nonynoic acid. (VI, $\mathrm{R}_{1}=$ $\left.\mathrm{CH}_{3}, \mathrm{R}_{2}, \mathrm{R}_{4}=\mathrm{H}, \mathrm{R}_{3}=\mathrm{CH}_{3}\left(\mathrm{CH}_{2}\right)_{3^{-}}\right)$. Carboxylation of $14 \mathrm{~g}(0.1 \mathrm{~mole})$ of the above described alcohol gave $7.5 \mathrm{~g}(40.7 \%)$ of the acid as a colorless liquid.

E) Lactone of 5-hydroxy-4-methyl-2-nonenoic acid. A methanol solution of $6.2 \mathrm{~g}$ ( 34.7 mmoles) of 5-hydroxy4-methyl-2-nonynoic acid was partially hydrogenated, and $3.4 \mathrm{~g}(58.2 \%)$ of the lactone was obtained. Bp $128 \sim 131^{\circ} \mathrm{C} / 5 \mathrm{~mm} . \quad n_{\mathrm{D}}^{20} 1.4675$. Anal. Found: C, 71.41; $\mathrm{H}, 9.65$, Calcd. for $\mathrm{C}_{10} \mathrm{H}_{16} \mathrm{O}_{2}: \mathrm{C}, 71,39 ; \mathrm{H}, 9.59 \%$. 
Lactone of 4-ethyl-5-hydroxy-2-octenoic acid (VIII)

A) 1-Pentyne-3-ol. (III, $\mathrm{R}_{1}=\mathrm{CH}_{3} \mathrm{CH}_{2-}, \mathrm{R}_{2}=\mathrm{H}$ ). From $58.0 \mathrm{~g}$ ( $1.0 \mathrm{~mole})$ of propionaldehyde $50.2 \mathrm{~g}(60 \%)$ of the alcohol was obtained. $\mathrm{Bp} 121 \sim 124^{\circ} \mathrm{C}$.

B) 3-Bromo-1-pentyne. (IV, $\mathrm{R}_{1}=\mathrm{CH}_{3} \mathrm{CH}_{2-}, \mathrm{R}_{2}=\mathrm{H}$ ). Bromination of $33.6 \mathrm{~g}$ (0.4 mole) of 1-pentyne-3-ol gave $26.5 \mathrm{~g}(45 \%)$ of the bromide. Bp $58 \sim 64^{\circ} \mathrm{C} / 96 \mathrm{~mm}$.

C) 3-Ethyl-1-heptyne-4-ol. (V, $\mathrm{R}_{1}=\mathrm{CH}_{3} \mathrm{CH}_{2}-, \mathrm{R}_{2}$, $\mathrm{R}_{\mathbf{4}}=\mathrm{H}, \quad \mathrm{R}_{\mathbf{3}}=\mathrm{CH}_{3}\left(\mathrm{CH}_{2}\right)_{2-}$,). This was prepared from $10.8 \mathrm{~g}(0.15$ mole $)$ of butanal and $22 \mathrm{~g}$ (0.15 mole) of 3-bromo-1-pentyne by the general method. Yield $10.4 \mathrm{~g}(49.3 \%) . \quad$ Bp $61 \sim 75^{\circ} \mathrm{C} / 6 \mathrm{~mm} . \quad n_{\mathrm{D}}^{22} 1.4362$.

D) 4-Ethyl-5-hydroxy-2-octynoic acid. (VI, $\mathrm{R}_{\mathbf{1}}=$ $\left.\mathrm{CH}_{3} \mathrm{CH}_{2-}, \mathrm{R}_{2}, \mathrm{R}_{4}=\mathrm{H}, \quad \mathrm{R}_{3}=\mathrm{CH}_{3}\left(\mathrm{CH}_{2}\right)_{2}^{-}\right)$. From $9.8 \mathrm{~g}$ (0.07 mole) of 3-ethyl-1-heptyne-4-ol the acid was obtained as a colorless crystalline solid. Yield $5.7 \mathrm{~g}$ (44\%). Recrystallization from ether and pet. ether gave colorless needles. Mp $105 \sim 107^{\circ} \mathrm{C}$. Anal. Found: C, 65.02; H, 8.51. Calcd. for $\mathrm{C}_{10} \mathrm{H}_{16} \mathrm{O}_{3}: \mathrm{C}, 65.19 ; \mathrm{H}$, $8.75 \%$

E) Lactone of 4-ethyl-5-hydroxy-2-octenoic acid. Partial hydrogenation of $5.2 \mathrm{~g}$ ( 28 mmoles) of the acetylenic acid gave $3.5 \mathrm{~g}(74.3 \%)$ of the lactone. Bp 133 137 ${ }^{\circ} \mathrm{C} / 7 \mathrm{~mm}$. $n_{\mathrm{D}}^{21}$ 1.4706. Anal. Found: C, 71.18; $\mathrm{H}$; 9.42. Calcd. for $\mathrm{C}_{10} \mathrm{H}_{16} \mathrm{O}_{2}: \mathrm{C}, 71.39 ; \mathrm{H}, 9.59 \%$.

\section{Lactone of 5-hydroxy-4-pentyl-2-pentenoic acid $(I X)$}

A) 1-Octyne-3-ol. (III, $\left.\mathrm{R}_{1}=\mathrm{CH}_{3}\left(\mathrm{CH}_{2}\right)_{4}-, \mathrm{R}_{2}=\mathrm{H}\right)$. Acetylation of $50 \mathrm{~g}$ ( 0.5 mole) of hexanal in liquid ammonia gave $26.0 \mathrm{~g}(41.2 \%)$ of 1-octyne-3-ol. Bp $85 \sim$ $87^{\circ} \mathrm{C} / 21 \mathrm{~mm} . n_{\mathrm{D}}^{20} 1.4431$.

B) 3-Bromo-1-octyne. (IV, $\mathrm{R}_{1}=\mathrm{CH}_{3}\left(\mathrm{CH}_{2}\right)_{4}-, \mathrm{R}_{2}=\mathrm{H}$ ). From $25.2 \mathrm{~g}(0.2 \mathrm{~mole})$ of the corresponding alcohol $23.7 \mathrm{~g}(62.5 \%)$ of the bromide was obtained. Bp $100 \sim$ $104^{\circ} \mathrm{C} / 50 \mathrm{~mm}$.

C) 3-Pentyl-1-butyne-4-ol. (V, $\mathrm{R}_{1}=\mathrm{CH}_{3}\left(\mathrm{CH}_{2}\right)_{4^{-}}, \mathrm{R}_{2}$, $\left.\mathrm{R}_{3}, \mathrm{R}_{4}=\mathrm{H}\right)$. This was prepared from $13.0 \mathrm{~g}(68.7$ mmoles) of 3-bromo-1-octyne and formaldehyde which was obtained from paraformaldehyde.4 Yield $5.6 \mathrm{~g}$ (58.2\%). Bp $90 \sim 93^{\circ} \mathrm{C} / 30 \mathrm{~mm} . \quad n_{\mathrm{D}}^{20} 1.4542$.

D) 5-Hydroxy-4-pentyl-2-pentynoic acid. (VI, $\mathrm{R}_{1}=$

4) H. Gilman and W.E. Catlin, "Organic Syntheses", Coll. Vol. I, p. 188.
$\left.\mathrm{CH}_{3}\left(\mathrm{CH}_{2}\right)_{4^{-}}, \mathrm{R}_{2}, \mathrm{R}_{3}, \mathrm{R}_{4}=\mathrm{H}\right)$. Grignard's reagent of $4.9 \mathrm{~g}$ ( $35 \mathrm{mmoles}$ ) of the corresponding alcohol was carboxylated in an autoclave gave $3.0 \mathrm{~g}$ (46.6\%) of the acetylenic acid as a colorless viscous liquid.

E) Lactone of 5-hydroxy-4-pentyl-2-pentenoic acid. Three grams (16.3 mmoles) of the acetylenic acid were partially hydrogenated to give $1.8 \mathrm{~g}(65.6 \%)$ of the lactone. Bp $133 \sim 140^{\circ} \mathrm{C} / 4 \mathrm{~mm}$. $n_{\mathrm{D}}^{23} 1.4685$. Anal. Found: $\mathrm{C}, 71.01 ; \mathrm{H}, 9.63$. Calcd. for $\mathrm{C}_{10} \mathrm{H}_{16} \mathrm{O}_{2}$ : $\mathrm{C}$, $71.39 ; \mathrm{H}, 9.59 \%$.

\section{Lactone of 4,4-dimethyl-5-hydroxy-2-octenoic acid $(X)$}

B) 3-Bromo-3-methyl-1-butyne. (IV, $\mathrm{R}_{1}, \mathrm{R}_{2}=\mathrm{CH}_{3}$ ). This was prepared from $25 \mathrm{~g}$ ( 0.3 mole) of 3-methyl1-butyne-3-ol. Yield $15.5 \mathrm{~g}(36.7 \%)$. Bp $95 \sim 100^{\circ} \mathrm{C}$.

C) 3,3-Dimethyl-1-heptyne-4-ol. (V, $\mathrm{R}_{1}, \mathrm{R}_{2}=\mathrm{CH}_{3}$, $\left.\mathrm{R}_{3}=\mathrm{CH}_{3}\left(\mathrm{CH}_{2}\right)_{2}{ }^{-}, \mathrm{R}_{4}=\mathrm{H}\right)$. The Reformatsky reaction of $7.2 \mathrm{~g}$ (0.1 mole) of butanal and $15 \mathrm{~g}(0.1 \mathrm{~mole})$ of 3-bromo-3-methyl-1-butyne by the general method gave $3.7 \mathrm{~g}(26 \%)$ of the alcohol. Bp $95 \sim 103^{\circ} \mathrm{C} / 47 \mathrm{~mm}$. $n_{\mathrm{D}}^{20} 1.4469$.

D) 4,4-Dimethyl-5-hydroxy-2-octynoic acid. (VI, $\mathrm{R}_{1}$, $\left.\mathrm{R}_{2}=\mathrm{CH}_{3}, \mathrm{R}_{3}=\mathrm{CH}_{3}\left(\mathrm{CH}_{2}\right)_{2}-, \mathrm{R}_{4}=\mathrm{H}\right)$. Carboxylation of $5.7 \mathrm{~g}$ ( $4 \mathrm{l}$ mmoles) of the acetylenic alcohol gave $2.3 \mathrm{~g}$ $(30.5 \%)$ of the acid as a colorless crystalline solid. Recrystallization from ether and pet. ether gave colorless needles. Mp $115 \sim 116^{\circ} \mathrm{C}$. Anal. Found: C, 64.93; $\mathrm{H}$, 8.55. Calcd. for $\mathrm{C}_{10} \mathrm{H}_{16} \mathrm{O}_{3}: \mathrm{C}, 65.19 ; \mathrm{H}, 8.75 \%$.

E) Lactone of 4,4-dimethyl-5-hydroxy-2-octenoic acid. This was prepared from $2.0 \mathrm{~g}$ ( 11 mmoles) of the acetylenic acid by hydrogenation. Yield $1.1 \mathrm{~g}(63.6 \%)$. BP $127 \sim 131^{\circ} \mathrm{C} / 7 \mathrm{~mm}$. $n_{\mathrm{D}}^{22} 1.4656$. Anal. Found: $\mathrm{C}$, 70.64; $\mathrm{H}, 9.60$. Calcd. for $\mathrm{C}_{10} \mathrm{H}_{16} \mathrm{O}_{2}: \mathrm{C}, 71.39 ; \mathrm{H}$ $9.59 \%$.

\section{Lactone of 5-hydroxy-4-methyl-2-decenoic acid (XI)}

C) 3-Methyl-1-nonyne-4-ol. (V, $\mathrm{R}_{1}=\mathrm{CH}_{3}, \mathrm{R}_{2}, \mathrm{R}_{4}=\mathrm{H}$, $\left.\mathrm{R}_{3}=\mathrm{CH}_{3}\left(\mathrm{CH}_{2}\right)_{4}^{-}\right)$. By the Reformatsky reaction of $6.7 \mathrm{~g}$ (67 mmoles) of hexaldehyde and $8.9 \mathrm{~g}$ (67 mmoles) of 3-bromo-1-butyne $3.6 \mathrm{~g} \mathrm{(34.9 \% )}$ of the alcohol was obtained. Bp $82 \sim 85^{\circ} \mathrm{C} / 5 \mathrm{~mm}, \quad n_{\mathrm{D}}^{20} 1.4479$.

D) 5-Hydroxy-4-methyl-2-decynoic acid. (VI, $\mathrm{R}_{\mathrm{L}}=$ $\left.\mathrm{CH}_{3}, \mathrm{R}_{2}, \mathrm{R}_{4}=\mathrm{H}, \mathrm{R}_{3}=\mathrm{CH}_{3}\left(\mathrm{CH}_{2}\right)_{4}-\right)$. By treating 6.16g (40 mmoles) of the above described alcohol $3.2 \mathrm{~g}$ (40.25\%) of the acid was obtained as a colorless viscous liquid. 
E) Lactone of 5-hydroxy-4-methyl-2-decenoic acid. Partial hydrogenation of $3.2 \mathrm{~g}$ (16.1 mmoles) of the corresponding acid gave $1.8 \mathrm{~g}(62.1 \%)$ of the lactone as a mobile liquid with a butter cake flavor. Bp 140 $143^{\circ} \mathrm{C} / 5 \mathrm{~mm}$. $n_{\mathrm{D}}^{20}$ 1.4651. Anal. Found: $\mathrm{C}, 72.21 ; \mathrm{H}$, 9.47. Calcd. for $\mathrm{C}_{11} \mathrm{H}_{18} \mathrm{O}_{2}: \mathrm{C}, 72.49 ; \mathrm{H}, 9.95 \%$.

\section{Lactone of 4-ethyl-5-hydroxy-2-decenoic acid (XII)}

C) 3-Ethyl-1-nonyne-4-ol. (V, $\mathrm{R}_{1}=\mathrm{CH}_{3} \mathrm{CH}_{2-}, \mathrm{R}_{2}$, $\mathrm{R}_{4}=\mathrm{H}, \mathrm{R}_{3}=\mathrm{CH}_{3}\left(\mathrm{CH}_{2}\right)_{4}-$, ). Eighteen grams (0.18 mole) of hexanal and $26.5 \mathrm{~g}(0.18 \mathrm{~mole})$ of 3-bromo-1-pentyne were reacted by the general method, and $13.5 \mathrm{~g}$ (44.7\%) of the alcohol was obtained. Bp 98 104 ${ }^{\circ} \mathrm{C} / 5 \mathrm{~mm}$. $n_{\mathrm{D}}^{20}$ 1.4529. Anal. Found: C, 78.00; H, 11.93. Calcd. for $\mathrm{C}_{11} \mathrm{H}_{20} \mathrm{O}: \mathrm{C}, 78.51 ; \mathrm{H}, 11.98 \%$.

D) 4-Ethyl-5-hydroxy-2-decynoic acid. (VI, $\mathrm{R}_{1}=$ $\left.\mathrm{CH}_{3} \mathrm{CH}_{2^{-}}, \mathrm{R}_{2}, \mathrm{R}_{4}=\mathrm{H}, \mathrm{R}_{3}=\mathrm{CH}_{3}\left(\mathrm{CH}_{2}\right)_{4^{-}}\right)$. By treating $11.8 \mathrm{~g}$ (70 mmoles) of the acetylenic alcohol $4.5 \mathrm{~g}$ $(30.3 \%)$ of the acid was obtained as a crystalline solid. Recrystallization from ether and pet. ether gave colorless needles. $\mathrm{Mp} 83 \sim 85^{\circ} \mathrm{C}$. Anal. Found: C, 67.75; $\mathrm{H}$, 9.35. Calcd. for $\mathrm{C}_{12} \mathrm{H}_{20} \mathrm{O}_{3}: \mathrm{C}, 67.89 ; \mathrm{H}, 9.50 \%$.

E) Lactone of 4-ethyl-5-hydroxy-2-decenoic acid. A methanol solution of $4.3 \mathrm{~g}$ (20.3 mmoles) of the corresponding acid was partially hydrogenated, and $2.5 \mathrm{~g}$ $(63.1 \%)$ of the lactone was obtained. Bp $150 \sim 153$ ${ }^{\circ} \mathrm{C} / 5 \mathrm{~mm}$. $n_{\mathrm{D}}^{20} 1.4668$. Anal. Found: C, 73.26; $\mathrm{H}$,
10.31. Calcd. for $\mathrm{C}_{12} \mathrm{H}_{20} \mathrm{O}_{2}: \mathrm{C}, 73.43 ; \mathrm{H}, 10.27 \%$.

Lactone of 5-hydroxy-5-methyl-2-decenoic acid (XIII)

C) 4-Methyl-1-nonyne-4-ol. (V, $\mathrm{R}_{1}, \mathrm{R}_{2}=\mathrm{H}, \mathrm{R}_{3}=$ $\left.\mathrm{CH}_{3}\left(\mathrm{CH}_{2}\right)_{4^{-}}, \mathrm{R}_{4}=\mathrm{CH}_{3^{-}}\right)$. This was prepared from $25 \mathrm{~g}$ $(0.22$ mole) of $n$-amyl methyl ketone and $26.2 \mathrm{~g}(0.22$ mole) of propargyl bromide by the general method. 4-Methyl-1-nonyne-4-ol was obtained as a colorless liquid. Bp $76 \sim 79^{\circ} \mathrm{C} / 4 \mathrm{~mm}$. Yield $10.7 \mathrm{~g}(31.8 \%)$ $n_{\mathrm{D}}^{20}$ 1.4508. Anal. Found: C, 77.51; H, 11.95. Calcd. for $\mathrm{C}_{10} \mathrm{H}_{18} \mathrm{O}: \mathrm{C}, 77.87 ; \mathrm{H}, 11.76 \%$.

D) 5-Hydroxy-5-methyl-2-decynoic acid. (VI, $\mathrm{R}_{1}$, $\left.\mathrm{R}_{2}=\mathrm{H}, \quad \mathrm{R}_{3}=\mathrm{CH}_{3}\left(\mathrm{CH}_{2}\right)_{4^{-}}, \quad \mathrm{R}_{4}=\mathrm{CH}_{3}\right)$. From $10 \mathrm{~g}(65$ mmoles) of the corresponding alcohol $5.9 \mathrm{~g}$ (46.1\%) of the acid was obtained.

E) Lactone of 5-hydroxy-5-methyl-2-decenoic acid. Partial hydrogenation of $5.9 \mathrm{~g}$ ( $30 \mathrm{mmoles})$ of the acetylenic acid gave $4.6 \mathrm{~g}(84 \%)$ of the lactone. Bp $143 \sim 146$ ${ }^{\circ} \mathrm{C} / 5 \mathrm{~mm}$. $n_{\mathrm{D}}^{22} 1.4715$. Anal. Found: $\mathrm{C}, 71.86 ; \mathrm{H}$, 9.94. Calcd. for $\mathrm{C}_{11} \mathrm{H}_{18} \mathrm{O}_{2}: \mathrm{C}, 72.49 ; \mathrm{H}, 9.95 \%$.

Acknowledgement. The author wishes to express his sincerest thanks to Prof. M. Matsui, University of Tokyo, for his helpful guidance. Thanks are due to Dr. M. Mogi and Dr. T. Yokotsuka, Kikkoman Shoyu Co., Ltd., for their unfailing encouragement and Miss K. Inose for her technical assistance. 